\title{
Determinants of Vulnerability to Expected Poverty among French Bean Farmers in Kenya
}

\begin{abstract}
Noah Kibet ${ }^{1 *}$, Gideon Obare $^{2}$ and Job Lagat ${ }^{3}$
1Department of Agricultural Bio-systems and Economics, University of Kabianga, Kenya

${ }^{2,3}$ Department of Agricultural Economics and Business Management, Egerton University, Kenya Abstract

Poverty is increasing in rural areas of Kenya. The study examined factors influencing vulnerability of French beans farmers to expected poverty using Vulnerability to Expected Poverty approach on 492 randomly selected respondents. The study found a mean vulnerability to expected poverty of $19.6 \%$ which is below vulnerability threshold of 50\% indicating that majority of French bean farmers irrespective of Global-GAP certification status were invulnerable to expected poverty. However, majority of those who were expenditure (56.3 percent) and income poor ( 92.2 percent) are vulnerable to future poverty. Factors influencing vulnerability to expected poverty are asset value $(\mathrm{P}=0.000)$, net crop income $(\mathrm{P}=0.000)$, off-farm income $(\mathrm{P}=0.000)$, household size $(\mathrm{P}=0.000)$, age of household head $(\mathrm{p}=0.088)$, gender of household head $(\mathrm{P}=0.001)$ and distance to market $(\mathrm{P}=0.000)$. French beans farmers should practice farm diversification and expand acreage under Global-GAP certified French beans in order to increase income and expenditure and hence alleviate future poverty.
\end{abstract}

Key words: French Beans, Vulnerability, Poverty, Global-Gap Standards

DOI: $10.7176 / \mathrm{JESD} / 10-10-14$

Publication date:May $31^{\text {st }} 2019$

\section{Introduction}

Since independence, poverty reduction, disease eradication and health has been recognized as the key pillars to consider in policy formulation in order to attain progressive development and increased living standards of Kenyan citizens health (Republic of Kenya, 1965). To date, poverty is still a major challenge to the development and requires constant monitoring in order to understand its causes so as to effectively address it. Statistics indicate that, the probability of falling non-poor, moderately poor and extremely poor in rural areas in Kenya is 42,13 and 45 percent respectively. Shepherd et al. (2014) projected that over 10.57 million Kenyans will remain poor by the year 2030. According to Republic of Kenya (2005), rural poverty in Central region where Kirinyaga County is located range between 10-56 percent and the same trend is observed across constituency level. In Kirinyaga County, rural vulnerability to expected poverty stands at 31.9 percent, which is slightly higher than the national rate of 28.3 percent (Oxford Poverty and Human Development Initiative, 2017).

To overcome poverty in rural areas, at least 60,000 small-scale farmers in Kenya are increasing diversifying their farming activities towards production of French beans (Ebony Consulting International, 2001). However, the increasing awareness of healthy foods among consumers has seen the export and local markets increasingly demand French beans that are certified under private standards, mainly Global Good Agricultural Practices (Global-GAP). Global-GAP standards are implemented mainly on French beans produced for export markets in Europe (FPEAK, 2014). Studies indicates that production of vegetables in the presence of different institutional arrangements, expose farmers to varying degrees of losses, returns and risks (Tschirley et al., 2004). For instance, uptake of Global-GAP standards is accompanied by high but volatile returns due to price volatility (Asfaw et al., 2010a) and high costs (Humphrey, 2008; Muriithi et al., 2011). Being a risky business, the question here is that, will continued production of French beans in the face of Global-GAP standards move farmers out of poverty brackets in future?.

In Kenya many studies on the impact of French beans production in the face of Global-GAP standards on household welfare have been based on the concept of observed poverty (,Humphrey, 2008; Asfaw et al., 2009; Asfaw et al., 2010; Muriithi et al., 2011). According to Chaudhuri (2000) and Chaudhuri (2003), observed poverty is seen as static or poverty defined at a single point in time. Static poverty analysis generates information on who is poor today and not and the characteristics of those who are poor but neglects those who are likely to be poor in future. Empirical studies on poverty have shown that, those who are not poor today may be poor tomorrow (Dercon and Krishnan, 2000; Yaqub, 2000; Chaudhuri, 2002; McKay and Lawson, 2002). Static poverty analysis tells very little about the dynamic processes that push households to poverty or move from poverty Deressa (2013). According to Chaudhuri et al. (2001), formulation of policies aimed at poverty eradication based on information 
generated from static poverty analysis is ineffective. The study further noted that, effective poverty prevention and reduction should therefore take account of clear understanding of vulnerability to poverty. This will help put in place effective policies and strategies to prevent future poverty.

The concept of dynamic poverty is therefore increasingly gaining popularity in poverty analysis. This is because the changes in vulnerability to future poverty are linked to static poverty levels over time (Bidani and Richter, 2001). Vulnerability to expected poverty is defined as the likelihood or probability of one falling into poverty or reduction in one's well-being in future (Pritchett et al., 2000; World Bank, 2000). According to Chaudhuri (2002) defines it as a forward-looking ex-ante measure of household's well-being that shows that irrespective of whether a household is poor today or not, may be poor tomorrow. The difference between observed poverty and vulnerability to expected poverty situations is explained by the presence and changes in risks and shocks within the environment in which decision makers operate in.

According to Dercon (2004), changes in consumption and welfare of individuals are caused by shocks and the changes in households' consumption levels over time determine households' vulnerability to poverty. Households face two types of shocks and risks namely covariate or idiosyncratic. Idiosyncratic shocks are those that are specific to a household and include illness, death of a household member, household member loosing employment, household size and age of household head among other factors (Chaudhuri et al., 2002; Dercon et al., 2005). According to Christiansen and Subbarao (2004), such shocks create unstable household income. According to Jacoby and Skoufias (1997), such shocks may lead to irreversible losses such as distress sale of productive assets, reduced nutrient intake, or interruption of education that permanently reduces human capital.

The study was guided by the need to generate information on the link between the shocks and French beans farmer's future poverty in order to help in early formulation of effective poverty alleviation strategies as recommended in Chaudhuri (2003). The information will also help farmers identify in advance risks and possible shocks that are likely to occur and the relevant strategies to embrace in order to prevent the occurrence of such risks. Information on household future poverty and its determinants is critical in informing National and County Government policies with respect to poverty eradication at the grass root level. The generated information will also help in future poverty benchmarks, within and between various Counties in the Country as well as informing the public on what they require to do to mitigate the increasing poverty and in guiding resource allocation at national level (KNBS and SID, 2014).

\section{Material and Methods}

\subsection{Study area}

The study was conducted in Kirinyaga County, within Kirinyaga Central, Kirinyaga East, Kirinyaga West, Mwea East and Mwea West Sub-counties because of concentration of French bean farmers and implementation of Global-GAP standards in the Sub-counties. Kirinyaga County is located 120 Kilometers North West of Nairobi and has a total population of 153,095 (Economic Survey, 2009). A part from French beans, rice, maize and horticulture (Onions, tomato, snow peas, avocado, mango and pawpaw) are also commonly grown in the County. French beans are mainly produced under irrigation and rain-fed.

\subsection{Sample size}

Lists of French bean farmers were obtained from Kirinyaga County Agricultural Office, farmer groups and exporters of French beans operating in the County. The lists were used to generate a sampling frame of 1,943 respondents (both certified and non-certified French bean farmers). Systematic random sampling procedure was then used to draw the sample size of 492 respondents consisting of 294 certified and 198 non-certified French bean farmers. The recommended sample size given a population of 1,943 is 322 but due to the availability of resources for data collection and the need to increase accuracy, the sample size was increased to 492 respondents. The sample size of 492 was proportionally distributed within the five Sub-Counties based on Global-GAP certification status and population of each Sub-County in the sampling frame. The sample size was computed as follows using formula developed by Krejcie and Morgan (1970):

$$
S=\frac{X^{2} N P(1-P)}{d^{2}(N-1)+X^{2} P(1-P)}
$$


where $S$ is the required sample size, $X^{2}=$ the table value of chi-square for 1 degree of freedom at the desired confidence level $(1.96 \times 1.96=3.84), N=$ Population size $P=$ Population proportion (assumed to be 0.50$), d=$ degree of accuracy expressed as a proportion (0.05). Using the formula, sample size corresponding to $N=1,943$ is 322 but the sample size was increased to 492 during data collection.

\subsection{Sampling procedure}

The study adopted multistage sampling procedure in the selection of respondents. Within Kirinyaga County: Kirinyaga Central, Kirinyaga East, Kirinyaga West, Mwea East and Mwea West Sub-Counties were purposively selected because this is where French beans are mainly produced. French bean farmers in each Sub-County were then stratified into two groups: Global-GAP certified and non-certified farmers. Sampling frames for the certified and non-certified French bean farmers were then generated for each Sub-County with the help of farmer group leaders and County Agricultural Officers. Systematic random sampling procedure was then applied to select the certified and non-certified French beans farmers from the sampling frames. Both certified (294) and non-certified (198) French bean farmers were selected proportionately depending on the size of sampling frames in each SubCounty and Global-GAP certification status to give a total sample size of 492 respondents.

\subsection{Ethical considerations}

Formal consent to carry out the study was sought from Graduate school, Egerton University, National Research Fund, County Agricultural Office and French bean farmer organizations and participation of respondents was purely voluntary.

\subsection{Data and data analysis}

Single cross-sectional data was used in the study. Data was obtained from the 492 randomly selected respondents using semi-structured questionnaire and covered 2014 cropping season. Both structured and unstructured questionnaires were used to solicit data. Data on household socio-economic, psychological and institutional characteristics were collected. Non-normal data were log transformed to approach normality. T-test and Chisquare tests were performed in the analysis. Data analysis was done using SPSS and STATA computer software. Results were then presented in form of tables.

\subsection{Estimation strategy}

Theoretical framework of this study was based on "risk chain" concept which assumes that, link exist between shocks and risks facing households, activities households choose, households' incomes, households' consumption levels and their vulnerability to future poverty (Chaudhuri 2003; Chaudhuri et al., 2002; Hoddinott and Quisumbing, 2008). Given the risk chain concept, an individual is assumed vulnerable to poverty if he/she is consumption poor. The link between consumption and vulnerability to poverty concept is widely applied in studies on poverty analysis across the globe. Most of these studies share the same definition of vulnerability to expected poverty with respect to household consumption. For instance, Skoufias (2002) defined vulnerability to risk as the degree to which the growth rate of household consumption co- varies with the growth rate of household income. Pritchett et al. (2000), Quisumbing (2002) and Chaudhuri et al. (2002) define vulnerability to future poverty as the likelihood that a household will find itself consumption-poor in the near future. World Bank defines vulnerability as "the likelihood of being adversely affected by a shock that usually causes consumption levels, or other factors that affect well being to drop (World Bank, 2001).

There are three methods of estimating household vulnerability to poverty: Vulnerability as Expected Poverty (VEP) approach, Vulnerability as low Expected Utility (VEU) approach and Vulnerability as uninsured Exposure to Risk (VER) approach (Chaudhuri et al., 2002). VEP and VEU approaches determine probability of a household falling below a predetermined poverty line while VER approach does not construct probabilities. In addition, VEP and VEU approaches measure vulnerability to future poverty at an individual/household level and it is possible to aggregate the individual measures of vulnerability to a single measure. VEP approach predicts the future impact of shocks while VER approach evaluates current impact of shocks. Cross sectional data can be used in VEP and VEU approaches while VER approach requires time series or panel data (Hoddinott and Quisumbing 2008). Since cross-sectional data was used in this study, VEP approach was adopted. 


\subsubsection{Vulnerability to expected poverty approach}

Vulnerability as Expected Poverty (VEP) approach as originally proposed by Chaudhuri et al. (2002) was adopted. This is because of availability of single cross-sectional data. VEP approach assumes that a household let say $h$ in time $t$ becoming vulnerable to future poverty, is the probability that the household is consumption poor in time $t$ +1 as illustrated in equation 2 .

$V_{h t}=\operatorname{Pr}\left(C_{h, t+1} \leq z\right)$

where $C_{h, t+1}$ is the per-capita consumption of household $h$ in time $t+1$ and $z$ is the consumption poverty line that is predetermined for benchmark purposes (Chaudhuri et al., 2002). There are two recommended consumption poverty lines namely standard threshold of 0.5 (50 percent) and mean poverty rate of a given population (Hoddinott and Quisumbing 2008). This study used a consumption expenditure based national poverty line of KES 2900 per month per adult equivalent. According to Deaton (1993), consumption expenditure of household $h$ at any period depend on factors such as: current income, expected income, uncertainty of future income, wealth and household's ability to smoothen consumption in the face of various shocks as shown in equation 3 .

$C_{h t}=c\left(X_{h}, \beta_{t}, \alpha_{h}, e_{h t}\right)$

where, $X_{h}$ represent observable characteristics of household $h, \beta_{t}$ represent a vector of parameters explaining the macro-economic environment at time $t, \alpha_{h}$ represent an unobserved time-invariant household-level effect and $e_{h t}$ represent idiosyncratic shocks that contribute to differences among households in terms of well-being (Chaudhuri et al., 2002). Equation 3 is substituted into equation 2 so that, vulnerability level of household $h$ can be obtained as follows:

$V_{h t}=\operatorname{Pr}\left(C_{h, t+1}=C\left(X_{h}, \beta_{t}+1, \alpha_{h}, e_{h}, t+1\right) \leq z \mid X_{h}, \beta_{t}, \alpha_{h}, e_{h t}\right)$

Equation 4 shows that, vulnerability level of household $h$ depend on the changes that occur in consumption levels of the household $h$ over time. The consumption levels of household $h$ over time are determined by household characteristics and changes in the setting in which the household operate in (environment). Equation 4 further shows that, multicollinearity and poverty trap are likely to occur. This is because; household's $h$ vulnerability level is determined by the future consumption prospects, which in turn influenced by current observed and unobserved household characteristics. Furthermore, aggregate shocks and changes in macro-economic environment, denoted by $\beta t$, influences vulnerability level of household $h$ (Chaudhuri et al., 2002). Since vulnerability of household $h$ to expected poverty depend on its expected mean consumption and changes on its consumption stream over time, both the expected mean and variance of the household consumption level are estimated in order to determine vulnerability to poverty. This estimation requires time series or panel data to allow direct estimation of inter-temporal variance of consumption at the household-level without any assumption.

However, because of unavailability and unreliability of time series data in developing countries, Chaudhuri et al. (2002) developed a model that predicts household's vulnerability to expected poverty using single cross-sectional data. Nevertheless, for one to use such a model, strong assumptions need to be made on the stochastic process that generates consumption. The stochastic process generating the consumption of household $h$ is specified as:

$\ln C_{h}=X_{h} \beta+e_{h}$

In equation $5 \ln C_{h}$ is $\log$ per capita consumption expenditure of household $h, X_{h}$ represents observable characteristics of household $h, \beta$ is a vector of parameters and $e_{h}$ is an error term (with mean-zero) that captures idiosyncratic shocks that explain the differences among households in terms of per capita consumption levels. According to Chaudhuri et al. (2002), the idiosyncratic shocks are assumed to be identical and independently distributed over time for each of the households. Without time series data, it is not possible to identify parameters that determine an individual consumption levels and the stochastic process generating $\beta$. In such cases, the variance of $e_{h}$ and $\ln C_{h}$ is allowed to depend on observable household characteristics in some parametric way (Equation 6).

$\sigma_{e, h}^{2}=X_{h} \theta$

A three-step Feasible Generalized Least Squares (FGLS) is then used to estimate $\beta$ and $\theta$, a procedure outlined in Amemiya (1977). According to Chaudhuri et al. (2002), equation 5 is estimated first by use of ordinary least squares (OLS) procedure. The resulting estimates are then used to estimate the following equation: 


$$
\hat{e}^{2} \text { oLS,h}=X_{h} \theta+\eta_{h}
$$

Using OLS procedure and estimates from equation 6, equation 7 is further transformed as follows:

$$
\frac{\hat{e}^{2}{ }_{O L S, h}}{X_{h} \hat{\theta}_{O L S}}=\left(\frac{X_{h}}{X_{h} \hat{\theta}_{O L S}}\right) \theta+\frac{\eta_{h}}{X_{h} \hat{\theta}_{O L S}}
$$

OLS procedure is then used to estimate equation 8 in order to obtain an asymptotically efficient FGLS estimate denoted as $\hat{\theta}_{F G L S} \cdot X_{h} \hat{\theta}_{F G L S}$ is a consistent estimate of the variance of idiosyncratic component of household 2 consumption $\sigma_{e, h}$. The variance is estimated as follows:

$$
\hat{\sigma}_{e, h}=\sqrt{X_{h} \hat{\theta}_{F G L S}}
$$

The estimated variance is then used to transform equation 5 as follows:

$$
\frac{\ln C_{h}}{\hat{\sigma_{e, h}}}=\left(\frac{X_{h}}{\hat{\sigma_{e, h}}}\right) \beta+\frac{e_{h}}{\hat{\sigma_{e, h}}}
$$

Estimation of equation 4 using OLS procedure yields a consistent and asymptotically efficient estimate of $\beta$. The standard error of the estimated coefficient $\hat{\beta}_{F G L S}$ was then be obtained by dividing the reported standard error by the standard error of the regression. Expected log consumption and variance of log consumption of each household are then directly estimated using $\beta$ and $\theta$ estimates Chaudhuri et al. (2002) as shown in equation 11 and 12 respectively.

$$
\begin{aligned}
& \hat{E}\left[\ln C_{h} \mid X_{h}\right]=X_{h} \hat{\beta} \\
& \hat{V}\left[\ln C_{h} \mid X_{h}\right]=\hat{\sigma}_{e, h}{ }^{2}=X_{h} \hat{\theta}
\end{aligned}
$$

It was assumed that $\ln C_{h}$ is normally distributed so that, the estimates in equation 11 and 12 were used to form an estimate of the probability that household $h$ with characteristics $X_{h}$ will be poor (Chaudhuri et al., 2002). This is given as.

$$
\hat{v}_{h}=\hat{\operatorname{Pr}}\left(\ln C_{h}<\ln z \mid X_{h}\right)=\phi\left(\frac{\ln z-X_{h} \hat{\beta}}{\sqrt{X_{h} \hat{\theta}}}\right)
$$

In equation (13), $\Phi$ represents cumulative density of the standard normal. The estimated variance was assumed equal for all households so that equation 5 is estimated using Ordinary Least Squares (OLS) to obtain an estimate of $\beta$ and the standard deviation of $e_{h}$ and $\ln C_{h}$. The estimates were then used to determine the probability that household $h$ with characteristics $X_{h}$ (See description of these characteristics in Table 1) will be poor in future. Vulnerability to expected poverty for each household was then compared with the predetermined poverty line $(z)$ such that, any household with VEP value equal to or above 0.5 was considered vulnerable to future poverty (Chaudhuri et al., 2002). 
Table 1: Description of factors influencing vulnerability to expected poverty

\begin{tabular}{lll}
\hline Variable & Description & Expected sign \\
\hline Vulnerability to future Poverty & 1=Non-vulnerable, 0=Vulnerable & None \\
Global-GAP Certification status & Certified=1, Non-certified=0 & + \\
Location & Sub-Counties & $+/$ \\
Asset value per adult equivalent & KES & + \\
Household size & Number of members per household & $+/$ \\
Household head age & Years & $+/-$ \\
Gender of household head & 1=Male, 0=Female & $+/-$ \\
Marital status & Categorical & $+/-$ \\
Total land size owned & Acres & + \\
Risk preferences & Categorical & $+/-$ \\
Group membership & $1=$ Yes, 0=No & + \\
Number of times household head sick & Numbers & - \\
Net livestock income & KES & + \\
Off-farm income & KES & + \\
Net crop income & KES & + \\
\hline
\end{tabular}

\section{Results and Discussions}

\subsection{Mean monthly consumption expenditure per adult equivalent}

On average, households of French bean farmers, irrespective of whether certified or not certified spend KES 7,292 per month per adult equivalent (Table 2).

Table 2: Mean consumption expenditure

\begin{tabular}{lllll}
\hline Variable & Mean $(\mathbf{N}=\mathbf{4 9 2})$ & Std. Dev. & Min & Max \\
\hline $\begin{array}{l}\text { Mean consumption expenditure per } \\
\text { month per adult equivalent }\end{array}$ & 7,292 & 25,682 & 160 & 477,381 \\
\hline
\end{tabular}

This figure is above the national consumption based poverty line of KES 2,900 expenditure per month per adult equivalent. Given the poverty line and the consumption expenditure, the results suggest that on average French bean farmers in Kirinyaga County are not poor.

\subsection{French beans farmers' mean vulnerability to expected poverty}

On average, French bean farmers, irrespective of whether certified or not, were not vulnerable to expected poverty as indicated by vulnerability level of 0.196 (19.6 percent), which is below the vulnerability threshold of 50 percent (Table 3).

Table 3: Mean vulnerability to expected poverty

\begin{tabular}{llllc}
\hline Variable & Mean & Standard Error & \multicolumn{2}{l}{$[\mathbf{9 5 \%}$ Confidence interval] } \\
\hline $\begin{array}{l}\text { Mean vulnerability to expected } \\
\text { poverty }\end{array}$ & 0.196 & 0.0187 & 0.1597 & 0.2332 \\
\hline
\end{tabular}

\subsection{Vulnerability to expected poverty by French beans farmers' characteristics}

Results in Table 4 shows that, statistically, vulnerability to expected poverty did not vary according to GlobalGAP certification status $(\mathrm{Pr}=0.347)$, risk preferences $(\mathrm{Pr}=0.866)$, gender of the household head $(\operatorname{Pr}=0.169)$, group membership $(\mathrm{Pr}=0.309)$ and credit access $(\mathrm{Pr}=0.281)$ among French beans farmers. The reason why Global-GAP certification is not significantly related to the future poverty is because, income to be earned from producing the French beans will not be sufficient enough to drive French bean farmers out of poverty. The findings are in line with those of Masanjala (2006) who found that engagement in cash crop increases farmer's income but sometimes not sufficient enough to move households out of poverty. 
The results further show that, majority of those who are expenditure poor ( 56.3 percent) and income poor ( 92.2 percent) are vulnerable to future poverty. The vulnerability rates are higher than the national vulnerability rate of 28.3 percent, rural rate of 31.9 percent and Central Region of Kenya rate of 30.1 percent (Oxford Poverty and Human Development Initiative, 2017). The study confirms that, there is high likelihood that poverty among French beans farmers in Kirinyaga County will remain high in future unless proper interventions to mitigate the poverty are put in place. Given education, majority of those without education (4.7), primary education (64.1) and secondary education (28.9) are vulnerable to future poverty when compared to those with Certificate and Diploma (1.6) and Degree (0.8). Higher education levels are associated with high income from formal employment. High income increases household's expenditure on basic needs and wants thus reducing poverty. Similar findings are reported in Wasonga (2009).

Table 4: Respondent's characteristics by vulnerability to expected poverty

\begin{tabular}{|c|c|c|c|c|}
\hline Variable & $\mathbf{N}$ & Not Vulnerability & $\mathbf{N}$ & Vulnerable \\
\hline \multicolumn{5}{|l|}{ Certification status } \\
\hline non-certified & 142 & 39.1 & 56 & 43.8 \\
\hline Certified & 222 & 60.9 & 72 & 56.2 \\
\hline \multicolumn{5}{|l|}{ Risk preferences } \\
\hline I never like take risks & 17 & 4.67 & 6 & 4.7 \\
\hline In most cases I don't like take risks & 50 & 13.7 & 17 & 13.3 \\
\hline I sometimes like take risks & 99 & 27.2 & 28 & 21.9 \\
\hline In most cases I like take risks & 132 & 36.3 & 49 & 38.3 \\
\hline I always like take risks & 64 & 17.6 & 27 & 21.1 \\
\hline No response & 2 & 0.6 & 1 & 0.8 \\
\hline \multicolumn{5}{|l|}{${ }^{1}$ Expenditure poverty } \\
\hline Poor & 123 & 33.8 & 72 & $56.3 * * *$ \\
\hline not poor & 241 & 66.2 & 56 & $43.7 * * *$ \\
\hline \multicolumn{5}{|l|}{${ }^{2}$ Income poverty } \\
\hline Poor & 239 & 65.7 & 118 & $92.2 * * *$ \\
\hline not poor & 125 & 34.3 & 10 & $7.8 * * *$ \\
\hline \multicolumn{5}{|l|}{ Gender of $\mathrm{HH}$} \\
\hline Female & 48 & 13.2 & 11 & 8.6 \\
\hline Male & 316 & 86.8 & 117 & 91.4 \\
\hline \multicolumn{5}{|l|}{ Education level of $\mathrm{HH}$} \\
\hline No education & 3 & 0.8 & 6 & $4.7 * * *$ \\
\hline Primary education & 170 & 46.7 & 82 & $64.1 * * *$ \\
\hline Secondary education & 157 & 43.1 & 37 & $28.9 * * *$ \\
\hline Certificate and diploma & 31 & 8.5 & 2 & $1.6 * * *$ \\
\hline Degree & 3 & 0.8 & 1 & $0.8 * * *$ \\
\hline \multicolumn{5}{|l|}{ Group membership } \\
\hline Not a member of a group & 94 & 25.8 & 39 & 30.5 \\
\hline Member of a group & 270 & 74.2 & 89 & 69.5 \\
\hline \multicolumn{5}{|l|}{ Credit access } \\
\hline No credit access & 279 & 76.7 & 104 & 81.3 \\
\hline Credit access & 85 & 23.3 & 24 & 18.7 \\
\hline
\end{tabular}

$*, * *$ and $* * *$ means significant at 10,5 and 1 percent level of significance respectively. ${ }^{1}$ Expenditure poverty was determined based on poverty line of KES 2,900 per month while ${ }^{2}$ income poverty was determined based on $\$ 1.90$ income per adult equivalent poverty line. HH-Household head

\subsection{Determinants of vulnerability to poverty}

Determinants of vulnerability to poverty were estimated using Vulnerability to Expected Poverty Approach and results presented in Table 5 . 
Table 5: Determinants of vulnerability to poverty

\begin{tabular}{|c|c|c|c|c|c|c|}
\hline \multirow{2}{*}{\multicolumn{7}{|c|}{$\begin{array}{lcc}\text { Variable } & \text { B } & \text { S.E } \\
\text { Dependent variable: }{ }^{1} \text { Vulnerability to Expected Poverty }\end{array}$}} \\
\hline & & & & & & \\
\hline Never like take risks & 0.0652 & 0.4372 & 0.150 & 0.881 & -0.7917 & 0.9220 \\
\hline $\begin{array}{l}\text { In most cases don't like } \\
\text { take risks }\end{array}$ & 0.1015 & 0.4108 & 0.250 & 0.805 & -0.7037 & 0.9066 \\
\hline Sometimes like take risks & 0.3575 & 0.3974 & 0.900 & 0.368 & -0.4214 & 1.1364 \\
\hline $\begin{array}{l}\text { In most cases like take } \\
\text { risks }\end{array}$ & 0.8198 & 0.4194 & 1.950 & $0.051 *$ & -0.0022 & 1.6417 \\
\hline Always like take risks & 0.6978 & 1.0261 & 0.680 & 0.496 & -01.313 & 2.7089 \\
\hline Certification status & -0.1303 & 0.1762 & -0.740 & 0.459 & -0.4756 & 0.2150 \\
\hline Assets value PAE & -0.4309 & 0.0605 & -7.120 & $0.000 * * *$ & -0.5495 & -0.3124 \\
\hline No education & -5.5593 & 225.4922 & -0.020 & 0.980 & -447.5160 & 436.3974 \\
\hline Primary education & -6.9053 & 225.4916 & -0.030 & 0.976 & -448.8607 & 435.0500 \\
\hline Secondary education & -7.2872 & 225.4916 & -0.030 & 0.974 & -449.2426 & 434.6681 \\
\hline Tertiary education & -8.0017 & 225.4919 & -0.040 & 0.972 & -449.9578 & 433.9544 \\
\hline Household size & 1.2671 & 0.2377 & 5.330 & $0.000 * * *$ & 0.8011 & 1.7331 \\
\hline Age of $\mathrm{HH}$ & -0.5472 & 0.3211 & -1.700 & $0.088^{*}$ & -1.1765 & 0.0822 \\
\hline Gender of $\mathrm{HH}$ & 0.9689 & 0.2943 & 3.290 & $0.001 * *$ & 0.3922 & 1.5457 \\
\hline Group membership & -0.2437 & 0.1963 & -1.240 & 0.215 & -0.6285 & 0.1411 \\
\hline Net livestock income & -0.0245 & 0.0191 & -1.280 & 0.199 & -0.0620 & 0.0129 \\
\hline Off-farm income & -0.0749 & 0.0160 & -4.680 & $0.000 * * *$ & -0.1062 & -0.0435 \\
\hline Net crop income & -0.2023 & 0.0230 & -8.810 & $0.000 * * *$ & -0.2474 & -0.1573 \\
\hline Distance to the market & -0.4360 & 0.1081 & -4.030 & $0.000 * * *$ & -0.6479 & -0.2242 \\
\hline Constant & 13.9598 & 225.4969 & 0.060 & 0.951 & -428.0061 & 455.9256 \\
\hline Number of observation & 492 & & & & & \\
\hline LR $\operatorname{chi} 2(19)$ & 275.26 & & & & & \\
\hline Prob $>$ chi 2 & 0.0000 & & & & & \\
\hline Pseudo R2 & 0.4880 & & & & & \\
\hline
\end{tabular}

HH- Household Head. PAE-Per Adult Equivalent. *,** and *** means significant at 10, 5, and 1 percent level of significance respectively. ${ }^{1}$ Vulnerability to expected poverty was captured as: Vulnerable $=1$ and Not vulnerable $=0 . \mathrm{SE}-$ Standard Error.

Variable indicating Global-GAP certification status is statistically insignificant $(\mathrm{P}=0.459)$ indicating that income farmers receive from producing Global-GAP certified French beans (given several needs facing the households), will not guarantee poverty alleviation in future. Variable indicating asset value per adult equivalent is statistically significant $(\mathrm{P}=0.000)$ and negatively $(\mathrm{B}=-0.4309)$ influencing vulnerability to poverty of French bean farmers. Ceteris paribus, an increase in asset values by one Kenyan Shilling, vulnerability of French bean farmers to expected poverty will reduce by 43.1 percent and vice versa. The reason is that some asset accumulation coupled with an increase in value will cushion farmers from future poverty. Similar findings are reported in Gbetibouo (2009) who found that wealth accumulation enhances the ability of households to bear anticipated risks. Ajijola et al. (2011) also noted that, an increase in the household disposable assets such as stored grains and livestock by one unit reduces poverty by 0.0000127 units. Similar findings are also reported in Muyanga et al. (2006) and Mbakahya and Ndiema (2015). Achieng' (2014) however reported contrary findings that, ceteris paribus, an additional high valued asset positively influences severity of poverty by 0.280 times among French bean farmers in Kirinyaga County.

Household size is statistically significant $(\mathrm{P}=0.000)$ and positively $(\mathrm{B}=1.2671)$ influencing vulnerability to expected poverty. Ceteris paribus, increase in household size by one member increases vulnerability to expected poverty by 126.7 percent and vice versa. The explanation for this is that, increasing the number of household members while holding income constant leads to a decrease in the welfare of the all members due to high competition for the existing scarce resources. Similar findings are reported in Muyanga et al. (2006), Muriithi (2008), Meenakshi and Ray (2000), Swanepoel (2005), Dirway (2010), Damisa et al. (2011), Mok et al. (2011) and Achieng' (2014) who concur that an additional household member increases household poverty. For instance Achieng' (2014) found that an additional household member increases severity of poverty by 0.827 times among French beans farmers in Kirinyaga County. Contrary findings are reported in Megersa (2015) who found that, large family size is a good source of labour for the household in the future that will undermine vulnerability to poverty. 
Age of household head is statistically significant $(\mathrm{P}=0.088)$ and positively $(\mathrm{B}=-0.5472)$ influencing French beans farmers vulnerability to expected poverty. That is, Ceteris paribus, increase in the age of the household head by one year decreases vulnerability to expected poverty by 54.7 percent and vice versa. The explanation for this is that, household heads are household providers and as age increases, their strength and productivity decreases coupled with health problems. As a result, household expenditure increases with dwindling income opportunities thus increasing household probability of falling into future poverty (Igbalajobi et al., 2013). Similar findings are reported in Bogale et al. (2005) who found that as the age of household head increases, they tend to own more assets and experience changes in the structure of the family as children grow and leave the household or contribute in lab our force to various farm activities.

Gender of household head is statistically significant $(\mathrm{P}=0.001)$ and positively $(\mathrm{B}=0.9689)$ influencing French beans farmers' vulnerability to expected poverty. That is, Ceteris paribus, households headed by males are 0.9689 times more vulnerable to expected poverty and vice versa. Similar findings are reported in Hichaambwa et al. (2015) and Machio (2015). According to Hichaambwa et al. (2015), female headed households are less likely to be poor because they are more willing to participate in horticultural farming than male headed households. Machio (2015) found that male headed households in Kenya are 2 percent more likely to be poor compared to households that are headed by a female. The explanation for this is that, male headed households control household incomes and expenses, and since they are the sole decision makers, they might decide to spend the money on personal effects rather than on the household income generating activities thus leading his household being poor. On the other hand contrary findings are reported in Oyugi et al. (2000), Geda et al. (2005) and Githinji (2011).

Variable indicating French beans farmers who in most cases like taking risks is statistically significant $(\mathrm{P}=0.051$ and $\mathrm{B}=0.8198$ ) and positively relating to vulnerable to future poverty. This means that if farmers in Kirinyaga County continue producing French beans in the face of Global-GAP standards, while holding current acreage constant, their vulnerability to expected poverty will increases by 82 percent and vice versa. The reason is that, Global-GAP certification positively increases household's income, but the increase in French beans income is not sufficient enough to move the households out of poverty brackets. The findings are contrary to those of Mosley and Verschoor (2003) and Ghartey et al. (2014) who found that risk aversion increases poverty among farmers.

Net annual crop income $(\mathrm{P}=0.000$ and $\mathrm{B}=-0.2023)$ significantly and negatively influenced vulnerability to future poverty of French bean farmers. That is, ceteris paribus, an increase in net crop income by one Kenyan shilling, vulnerability to expected poverty decreases by 20.2 percent and vice versa. The findings concur with those of Muyanga et al. (2006) who found that income from crop diversification reduces household's probability of falling into poverty among Kenyan farmers. Hulme and McKay (2005) argue that crop failure is associated with household vulnerability to poverty.

Off-farm income $(\mathrm{P}=0.000$ and $\mathrm{B}=-0.0749)$ significantly and negatively influence vulnerability to future poverty of French bean farmers. That is, ceteris paribus, an increase in net crop income and off-income of French bean farmers by one Kenyan shilling, vulnerability to expected poverty decrease by 7.5 percent and vice versa. The reason is that, in most cases, agricultural income is seasonal and unpredictable, thus off-farm income or formal employment becomes one of the coping mechanisms that cushion farmers against observed and future poverty. The findings concur with those of Oyugi et al. (2000), Burke et al. (2007), Githinji (2011), Onyeiwu and Liu (2013) and Megersa (2015) who found that an increase in off-farm income cushion farmers from falling into poverty.

Distance to the nearest market is statistically significant $(P=0.000)$ and negatively $(B=-0.4360)$ influencing vulnerability of French beans farmers to future poverty. That is, ceteris paribus, increase in the distance to the nearest market by one kilometer, French beans farmers vulnerability to future poverty decreases by 43.6 percent and vice versa. The reason is that, local or farm gate markets do offer lower prices which translate to lower income. Lower income increases current and future poverty. Therefore far markets like those in Nairobi and in overseas (for instance European markets) offer higher prices which translate to more income and thus reduction in poverty. Contrary findings however are reported in Elhadi et al. (2012).

\section{Conclusions and Recommendations}

Results further indicate that majority of French beans farmers who were expenditure (56.3 percent) and income poor (92.2 percent) were vulnerable to future poverty. French beans farmers who in most cases like taking risks $(\mathrm{P}=0.051$ and $\mathrm{B}=0.8198)$ were more likely to be vulnerable to future poverty. That is, if farmers continue producing French beans in the face of Global-GAP standards, while holding current acreage constant, their 
vulnerability to expected poverty will increase by 82 percent and vice versa. The reason is that, although GlobalGAP certification significantly and positively increases household's income, the increase in income was not sufficient enough to move the households out of current and future poverty brackets. Other important factors influencing French beans farmers vulnerability to expected poverty include: asset value per adult equivalent $(\mathrm{P}=$ $0.000 \mid \mathrm{B}=-0.4309)$, household size $(\mathrm{P}=0.000 \mid \mathrm{B}=1.2671)$, age of household head $(\mathrm{P}=0.088 \mid \mathrm{B}=-0.5472)$, gender of household head $(\mathrm{P}=0.001 \mid \mathrm{B}=0.9689)$, net crop income $(\mathrm{P}=0.000 \mid \mathrm{B}=-0.2023)$, off-farm income $(\mathrm{P}=0.000 \mid \mathrm{B}$ $=-0.0749)$ and distance to the nearest market $(\mathrm{P}=0.000 \mid \mathrm{B}=-0.4360)$. The findings suggest that, French beans farmers should take more risks by continuing producing and expanding acreage under Global-GAP certified French beans in order to increase household income and expenditure and hence alleviating future poverty.

\section{References}

Achieng' O. R. 2014. Impact of Global-GAP Compliance on the Relative Poverty Status of Smallholder Horticultural Farmers in Eastern and Central Kenya. Department of Agricultural Economics, Faculty of Agriculture University of Nairobi., Nairobi, Kenya 2015. Available at https://www.google.com/?gws_rd=ssl\#q=Achieng\%E2\%80\%99+O.+R (last accessed 20 May 2016).

Ajijola, S., Egbetokun, O. A. and Ogunbayo, I. E. 2011. Impact of Risk Attitudes on Poverty Level among Rural Farmers in Ogun State, Journal of Development and Agricultural Economics, 3(12), (2011) pp. 581-587.

Amemiya, T. 1977. The Maximum Likelihood and the Nonlinear Three-Stage Least Squares Estimator in the General Nonlinear Simultaneous Equation Model. Econometrica, 45(4), (1977) pp. 955-968.

Asfaw, S., Mithöfer, D. and Waibel, H. 2009. Investment in Compliance with GlobalGAP Standards: Does it Pay-off for Smallscale Producers in Kenya? Quarterly Journal of International Agriculture, 48(4), (2009) pp. 337-362.

Asfaw, S., Mithöfer, D. and Waibel, H. 2010a. Agrifood Supply Chain, Private-sector Standards, and Farmers' Health: Evidence from Kenya. Agricultural Economics, 41(3-4), (2010a) pp. 251-263.

Asfaw, S., Mithöfer, D. and Waibel, H. 2010. What Impact Are EU Supermarket Standards Having on Developing Countries' Export of High-Value Horticultural Products? Evidence From Kenya. Journal of International Food and Agribusiness Marketing, 22(3-4), (2010) pp. 252-276.

Bidani, B. and Richter K. 2001. Household Vulnerability and the Asian Crisis: The Case of Thailand. World Bank, Washington, DC. 2001.

Bogale, A., Hagedorn, K and Korf, B. 2005. Determinants of Poverty in Rural Ethiopia. Journal of International Agriculture, 2: 101-120.

Burke, W.J., Jayne, T.S., Freeman, H.A. and Kristjanson, P. 2007. Factors Associated with Farm Households' Movement Into and Out of Poverty in Kenya: The Rising Importance of Livestock. Michigan State University, International Development Working Paper No. 90. http://www.aec.msu.edu/fs2/papers/idp.htm. Accessed on 14 ${ }^{\text {th }}$ July, 2016.

Chaudhuri S. 2000. Empirical Methods for Assessing Household Vulnerability to Poverty. Available at 2000.https://www.researchgate.net/publication/243788111_Empirical_Methods_for_assessing_household_vulnera bility_to_poverty (last accessed 19 May 2015).

Chauduri, S. 2002. Empirical Methods for Assessing Household Vulnerability to Poverty (Mimeo. Columbia University, New York, 2002).

Chaudhuri, S. 2003. Assessing Vulnerability to Poverty: Concepts. Empirical Methods and Illustrative Examples, 2003. Available at https://www.google.com/?gws_rd=ssl\#q=Chaudhuri, + S. $+(2003) .+$ Assessing+Vulnerability+to+Poverty:+Concepts.+Empirical+Methods+and+Illustrative+Examples.+ Department + of + Economics, + Columbia + University (last accessed 19 May 2015).

Chaudhuri S., Jalan, J. and Suryahadi. A. 2001. Assessing Household Vulnerability to Poverty from Cross-sectional Data: A Methodology and Estimates from Indonesia, Columbia University, Department of Economics, Discussion Paper Series, \#:0102-52, 2001.

Chaudhuri, S., Jalan J. and Suryahad A. 2002. Assessing Household Vulnerability to Poverty from Cross-sectional Data: A Methodology and Estimates from Indonesia. Discussion Paper Series, \#:0102-52. Columbia University, Department of Economics, New York.

Christiaensen, L. J. and Subbarao, K. 2004. Towards and Understanding of Vulnerability in Rural Kenya. World Bank Policy Research Working Paper 3326. 2004. World Bank, Washington, DC.

Damisa, M. A., Sanni, S. A. 2011. Abdoulaye, T., Kamara, A. Y. and Ayanwale, A. Household Typology Based Analysis of Livelihood Strategies and Poverty Status in the Sudan Savannah of Nigeria: Baseline Conditions. Learning Publics Journal of Agriculture and Environmental Studies, 2(1), (2011) pp. 146-160.

Deaton, A. 1993. Understanding Consumption. Oxford, New York: Oxford University Press, 1993.

Deressa, D. F. 2013. Assessing Households Vulnerability to Poverty in Rural Oromiya - Ethiopia. Journal of Economics and Sustainable Development, 4(8), (2013) pp. 110-117.

Dercon, S. 2004. Growth and Shocks: Evidence from rural Ethiopia. Journal of Development Economics, 74(2): 309-329.

Dercon, S. and Krishnan, P. 2000. Vulnerability, Poverty and Seasonality in Ethiopia. Journal of Development Studies, 36 (6), (2000) pp. 25-53.

Dercon, S., Hoddinott, J. and Woldehanna, T. 2005. Shocks and Consumption in 15 Ethiopian Villages, 1999--2004. Journal of African Economies, 14(4): 559-585.

Dirway, T. P. 2010. Application of the Sustainable Livelihood Framework to the Analysis of the Provincial Growth and Development Plan of the Eastern Cape - A Case Study of Mass Food Production Programme in Nkonkobe Municipality and Baffalo City Municipality 2010. 
Ebony Consulting International 2001. The Kenyan Green Bean Sub-sector. Department for International Development 2001. Available at https://www.google.com/?gws_rd=ssl\#q=The+Kenyan+Green+Bean+Subsector.+Department+for+International+Development (last accessed 18 May 2014).

Economic Survey. Kenya National Bureau of Statistics, 2009. Available at https://www.knbs.or.ke/download/economicsurvey-2009-3/ (last accessed 05 May 2017).

Elhadi, A. Y., Nyariki, D. M., Wasonga, V. O. and Ekaya, W. N. 2012. Factors Influencing Transient Poverty among AgroPastoralists in Semi-Arid Areas of Kenya. African Crop Science Journal, 20(1): 113-122.

Federation of Producers and Exporters Association of Kenya 2014. Kenya-GAP Successfully Re-benchmarked for GLOBALG.A.P. Integrated Farm Assurance Standard Version 4. 2014.. Available at http://www.globalgap.org/uk_en/media-events/news/articles (last accessed 05 May 2017).

Gbetibouo, G. A. 2009. Understanding Farmer's Perceptions and Adaptations to Climate Change and Variability: The Case of the Limpopo Basin Farmers South Africa. 2009. Available at http://cgspace.cgiar.org/handle/10568/21662 (last accessed 05 May 2017)

Geda, A., Jong, N., Kimenyi, M. and Mwabu, G. 2005. Determinants of Poverty in Kenya: A Household Level Analysis. KIPPRA Working Papers no 44, Nairobi: Kenya Institute for Public Policy Research and Analysis.

Ghartey, W., Dadzie, S. K. N. and Weittey, M. 2014. Poverty and Risk Attitudes: The Case of Cassava Farmers in Awutusenya District of the Central Region of Ghana. Asian Journal of Agricultural Extension, Economics \& Sociology, 3(2), (2014) pp. 164-178.

Githinji, M. 2011. Land, Poverty and Human Development: the Determinants of the Poverty Status of Rural Kenyan Households. Working Paper, University of Massachusetts, Amherst.

Hichaambwa, M., Chamberlin, J. and Kabwe S. 2015. Is Smallholder Horticulture the Unfunded Poverty Reduction Option in Zambia: A Comparative Assessment of Welfare Effects of Participation in Horticultural and Maize Markets. Working Paper No. 96

Hoddinott, J. and Quisumbing, A. R. 2008. Methods for Microeconometric Risk and Vulnerability Assessments. SSRN Scholarly Paper No. ID 1281055 (Rochester, NY: Social Science Research Network, 2008)

Hulme, D. and McKay, A. 2005. Identifying and Measuring Chronic Poverty: Beyond Monetary Measures, Paper Presented at the International Conference on the Many Dimensions of Poverty. 2005.

Humphrey, J. 2008. Private Standards, Small Farmers and Donor Policy: EUREPGAP in Kenya. 2008. Available at http://temp.ids.ac.uk/idspublication/private-standards-small-farmers-and-donor-policy-Eurep-GAP-in Kenya (last accessed on 10 October 2017).

http://www.businessdictionary.com/definition/certification.html (last accessed on 10 October 2017).

Igbalajobi, O., Fatuase, A. I. and Ajibefun, I. 2013. Determinants of Poverty Incidence among Rural Farmers in Ondo State, Nigeria. American Journal of Rural Development, 1(5): 131-137.

Jacoby, H. and Skoufias, E. 1997. Risk, Financial Markets and Human Capital in a Developing Country. Review of Economic Studies, 64 (X), (1997) pp. 311-335.

Kenya National Bureau of Statistics and Society for International Development. 2014.'Exploring Kenya's Inequality: Pulling a Part or Pooling Together?'. 2014. Available at https://www.knbs.or.ke/exploring-kenya-s-inequality-pulling-a part-or-pooling-together (last accessed on 10 October 2017).

Krejcie, R. V. and Morgan, D. W. 1970. Determining Sample Size for Research Activities. Educational and Psychological Measurement, 30(3): 607-610.

Machio, P. N. 2015. Determinants of Rural Poverty in Kenya: The Case of Cash Crop Growing. School of Economics, University of Nairobi, Kenya. http://erepository.uonbi.ac.ke/bitstream/handle/11295/95253/MachioDeterminants\%20Of\%20Rural\%20Poverty\%20In\%20Kenya\%20The\%20Case\%20Of\%20Cash\%20Crop\%20Grow ing.pdf? sequence $=1$. Accessed on $12^{\text {th }}$ June, 2018.

Masanjala, W. H. 2006. Cash Crop Liberalization and Poverty Alleviation in Africa: Evidence from Malawi. Agricultural Economics, 35:231-240.

Mbakahya, G.M and Ndiema, A.C. 2015. Farming Households' Vulnerability and Resilience to Climate Change in Nambale Sub-County of Kenya. International Journal of Science, Environment and Technology, 4(6), (2015) pp. 1608-1617.

Meenakshi, J. V. and Ray, R. 2000. Impact of Household Size and Family Composition on Poverty in Rural India. 2000. https://digitalcollections.anu.edu.au/bitstream/1885/40319/3/meenakshi.pdf (last accessed on 10 October 2017).

Megersa, D. 2015. Measuring Vulnerability to Poverty: An Empirical Evidence from Ethiopian Rural Household SurveyMaster's Thesis, Agricultural Economics and Management. Degree thesis No $904 \cdot$ ISSN 1401-4084. 2015. Swedish University of Agricultural Sciences, Uppsala. Retrieved from http://stud.epsilon.Slu.Se/7574/ (last accessed on 10 October 2017).

McKay, A. and Lawson, D. 2002. Chronic Poverty: A Review of Current Quantitative Evidence. Chronic Poverty Research Centre. Working Paper No 15. April 2002.

Mok, T.P., Maclean, G. and Dalziel P. 2011. Household Size Economies: Malaysian Evidence. Economic Analysis Policy, 41(2), (2011).

Mosley, P. and Verschoor, A. 2005. Risk Attitudes and the 'Vicious Circle of Poverty.' The European Journal of Development Research, 17(1), (2005) pp. 59-88.

Muriithi, B. W., Mburu, J. and Ngigi, M. 2011. Constraints and Determinants of Compliance With Eurep-gap Standards: A Case of Smallholder French Bean Exporters in Kirinyaga District, Kenya. Agribusiness, 27(2), (2011) pp. 193-204.

Muyanga, M., Ayieko, M. and Bundi, M. 2006. Transient and Chronic Rural Household Poverty: Evidence from Kenya. 2006. Available at $\mathrm{http} / / /$ citeseerx.ist.psu.edu/viewdoc/download?doi=10.1.1.545.1442\&rep=rep1\&type=pd. (last accessed on 10 October 2017). 
Onyeiwu, S. and Liu, J. 2013. Determinants of Income Poverty in Rural Kenya: An Empirical Analysis. Journal of Economic and Sustenance Development, 2: (1).

Oxford Poverty and Human Development Initiative 2017. "Kenya Country Briefing”, Multidimensional Poverty Index Data Bank. OPHI, University of $2017 . \quad$ Available at https://www.google.com/search?q=Available+at $\% 3 \mathrm{~A}+$ www.ophi.org.uk\%2Fmultidimensional-povertyindex $\% 2$ Fmpi-country-briefings $\% 2$ Fandie $=$ utf doe=utf8andclient=firefox-b-ab\#q=Available+at:+www.ophi.org.uk (last accessed on 10 October 2017).

Oyugi, N.L., Mwabu, G. and Masai, W. 2000. The Determinants of Poverty in Kenya. African Journal of Economic Policy, 7(1): 47-64.

Pritchett, L.; Suryahadi, A. and Sudarno, S. 2000. Quantifying Vulnerability to Poverty-a Proposed Measure, Applied to Indonesia. Policy Research Working Paper Series 2437. 2000.

Quisumbing, A. 2002. Consumption Smoothing, Vulnerability, and Poverty in Rural Bangladesh. Draft. IFPRI. Washington, DC. 2002.

Republic of Kenya 1965. African Socialism and its Application to Planning in Kenya. The Sessional Paper No. 10 of 1965. Government Printer. Nairobi.

Republic of Kenya 2005. Geographic Dimensions of Well-Being in Kenya. Who and Where are the Poor? A Constituency Level Profile. Volume II. Central Bureau of Statistics. Ministry of Planning and National Development. Nairobi Development. Nairobi. 2005.

Shepherd, A., Scott L., Mariotti, C., Kessy, F., Gaiha, R., Da Corta, L. and Wild, L. 2014. The Chronic Poverty Report 2014-2015: The Road to Zero Extreme Poverty. 2014. Available at http://pardee.du.edu/chronic-poverty-report2014\%E2\%88\%922015-road-zero-extreme-poverty (last accessed on 10 October 2017).

Skoufias, E. 2002. Measuring Household Vulnerability to Risk. Some Estimates from Russia. IFPRI, Washington, DC. 2002.

Swanepoel, C. 2005. Poverty and Poverty Dynamics in Rural Ethiopia (Working Papers No. 03, 2005. Stellenbosch University, Department of Economics. Available at https://ideas.repec.org/p/sza/wpaper/wpapers14.html (last accessed 06 July 2017).

Tschirley, D., Muendo, M. and Weber, M. 2004. Improving Kenya's Domestic Horticultural Production and Marketing System: Current Competitiveness, Forces of Change, and Challenges for the Future. Tegemeo Institute of Agricultural Policy and Development. 2004. Available at http://www.book.y-lib.info/17-political/592013-1-tegemeo-instituteagricultural-policy-and-development-working-paper.php (last accessed on 10 October 2017).

Wasonga, V.O. 2009. Linkages Between Land-Use, Land Degradation and Poverty in Semi-Arid Rangelands of Kenya: The Case of Baringo District. PhD Thesis, University of Nairobi, Kenya, Nairobi, Kenya.

World Bank 2000. World Development Report: Attacking Poverty (Oxford University Press, New York, 2000).

World Bank. 2001. World Development Report: Attacking Poverty. London: Oxford University Press.

Yaqub, S. 2000. Poverty Dynamics in Developing Countries. Development Bibliography. Brighton: Institute of Development Studies. Sussex, England. 2000. 